\title{
Chapter 13 \\ Gastronomy and Wines in the Alentejo Portuguese Region: Motivation and Satisfaction of Tourists from Évora
}

\author{
Rui Amaral, Margarida Saraiva, Susana Rocha, and Jaime Serra
}

\begin{abstract}
Food and winemaking are a recognized tangible and intangible culturalheritage of Portugal. From the relationshipbetween these twocomponents, astrategic product emerged with a considerable potential for tourism industry, which is notignored bymany of tourism organizations. This chapter intends to analyze food and winemaking from atourism demand perspective. Particularly, this study describes visitors' profile, including, their motivations, their knowledgeabout theenological and gastronomicresourcesand the degreeof satisfaction. A total of 308 questionnaires were collected between February and May of 2012, from the visitors that visited the historic center of Évora (Alentejo-Portugal). Results reveal a visitor profile associated with regional cuisine and wine products from Portugal. Moreover, visitors' evidenced a high level of knowledge regarding the Portuguese cuisine and regional wines; although this not matches with their primary motivation for visit the city of Évora.
\end{abstract}

R. Amaral $(\triangle)$

Management Department, EPRAL and University of Évora, Largo dos Colegiais, 2,

7000-803 Évora, Portugal

e-mail: ruialmeidaamaral@hotmail.com

M. Saraiva

Management Department, University of Évora and BRU-UNIDE/ISCTE-IUL,

Largo dos Colegiais, 2, 7000-803 Évora, Portugal

e-mail:msaraiva@uevora.pt

S. Rocha

Management Department, University of Évora, Largo dos Colegiais, 2,

7000-803 Évora, Portugal

e-mail: susanarocha2005@hotmail.com

J. Serra

Sociology Department, University of Évora, Largo dos Colegiais, 2,

7000-803 Évora, Portugal

e-mail: jserra@uevora.pt 